\title{
Old and new visions of Brazilianness: the vagaries of equality, difference and 'race' in history textbooks
}

\author{
Fabiano Dias Monteiro \\ Universidade Federal do Rio de Janeiro
}

\begin{abstract}
In this paper I discuss with the changes in Brazilian history textbooks brought about by the National Textbook Program (PNLD) during the 1980s, regard to put a greater emphasis on the value of democracy and questions of inequality, including those inequalities related to cultural differences, often in terms of "race". The analysis reveals a major paradigmatic shift from the notions of a nation built on "racial mixture" to one based on the tense and often conflictive relations between distinct racial and ethnic groups.
\end{abstract}

Keywords: National Textbook Program, racism

\section{Resumo}

Neste artigo irei me debruçar sobre as alterações observadas nos livros escolares brasileiros, em particular a partir do Programa Nacional do Livro Didático (PNLD), consolidado nos anos 1980 e sobre sua ênfase na valorização dos princípios democráticos e sua focalização nas desigualdades incluindo aquelas relacionadas às diferenças culturais, não raro tomadas em termos de "raça". A análise revela a transição de um paradigma de nação construído sobre a ideia de mistura racial para outro centrado na ideia de tensão e das relações de conflito entre grupos étnicos distintos.

Palavras-chave: Programa Nacional do Livro Didático, racismo 


\section{Old and new visions of Brazilianness: the vagaries of equality, difference and 'race' in history textbooks}

Fabiano Dias Monteiro

\section{Introduction}

With the return to democracy in Brazil following the end of the military dictatorship (1964-1985) the new political freedoms allowed for a series of demands from burgeoning social movements previously suppressed or curbed by the authoritarian state. These social movements - which ranged from organizations campaigning for agrarian reform and for the right to adequate housing in large urban centres to the so-called 'diffuse' or collective rights of groups like women, black people and homosexuals - had an increasing impact in the media and on the agendas of political parties as these emerged over the 1980s and gos. These campaigns widened the notion of citizenship in a society where historically the State had been the main distributor of rights; especially those conceded to workers in the formal sector and/or based on elitist and clientelist logics (Sorj 2000, Carvalho 2001). These processes were also accompanied by an endeavour to consolidate rights to basic services such as healthcare and education.

Since the latter topic is of particular interest here, it is worth noting that in the final decades of the twentieth century a national debate was still in progress concerning the limits posed to providing democratic access to quality education in the country. Some of the central points of this debate were the supposed decline in the quality of public education, the need for Brazil to train a skilled labour force capable of supporting economic growth and technological development (an argument still heavily inspired by the 'Economic Miracle' of the 1970s), the crusade against illiteracy and the 
possibilities for the social inclusion of the poor through an improvement in educational opportunities.

As an offshoot to various of these issues, the suitability of the existing school books to the aims of a democratic education system also came under heated discussion during the post-dictatorship period in Brazil, and indeed persists into the present.

Although I have no intention here to survey (or reconstruct) a "history of textbooks in Brazil," it should be emphasized that, as would be expected, the discourses built around them were permeated by political and ideological questions that varied over time.

In this article, I examine the changes to school books imposed by the National Textbook Program (Programa Nacional do Livro Didático: PNLD), introduced between the 1980 s and 1990s, especially in terms of ensuring content and visual imagery that questioned inequalities, promoted particular discourses in favour of democracy and respect for cultural differences (not infrequently understood in 'racial' terms).

I therefore compare books written before these changes that I call Traditional Approach Books (TABs) with those published during them, which I term Revisionist Approach Books (RABs). While the former have come to be termed reactionary, the latter are in principle committed to discourses that, in Brazil, have tended to be labelled progressive by the lay public (campaigning for social justice, minority rights, human rights, awareness of environmental issues, and so on).

As Benedict Anderson suggests in his classic Imagined Communities (2005), the sense of nationality can be seen to result from the combination of physical and symbolic resources that produce the feeling of shared experience among fellow citizens. Nation-ness, which goes beyond nationalism, transcends the ideological projects of building a territorial, military, linguistic and administrative unity generally pursued by States.

In this sense, nationality is something that is both empirical and fictional, internalizable insofar as it can produce situations (socioscapes) and personas ${ }^{1}$

\footnotetext{
1 I suggest the idea of sócio-personagens from what Benedict Anderson contributed with the term sóciopaisagens, considering them as figures able to incarnate certain aspects of what is supposed to be nation's characteristics. In this sense, the "Malandro" of Roberto DaMatta, the mistic "baianas" of Jorge Amado and the tenacious "sertanejo" from Euclides da Cunha would be examples of brazilian "sócio-personagens" in the light of Anderson's contribution.
} 
(socio-personagens) identifiable with the citizens of a nation and thus enable the recognition of continuities and similarities between individuals otherwise different by definition.

The physical media favoured for the dissemination of the socioscapes and socio-personagens, Anderson argues, is the printed page, especially newspapers and novels with a social message. In this sense, the graphic medium has become the main channel through which nation-ness flows in western culture with increasing speed and scope, above all due to the technological advances experienced in the twentieth century.

Taking into account the expansion in the production/consumption of textbooks across practically the entire planet over the last century, I argue that they perform a very specific role in the diffusion of socioscapes and socio-personagens, serving to disseminate both nation-ness and nationalist doctrines (Choppin 2004). The epicentre of the on-going discussion is the construction of a new ideal of Brazilianness involving the promotion of discourses celebrating democracy and universal citizenship. I shall therefore focus particularly on history books (the History of Brazil and General History, and supplementary teaching materials), making only occasional use of books from Geography, Sociology and Social Studies, which figured in the research a priori as contrasting elements.

The article has three main aims: to contextualize the impact of Brazil's re-democratization process on education in the country and analyse the State's repositioning vis-à-vis the production of teaching materials; to reposition the discourses of Brazilianness inserted in this process and to examine their interface with fields of knowledge such as nineteenth-century criminal anthropology, cultural anthropology (1930s), social history and Brazilian sociology (post-1950); and finally to initiate a reflection on how the reformulation of the materials has impacted on everyday life of the classroom based on the perceptions of teachers and other professionals linked to the teachinglearning relationship.

Allied with the perceptions of specialists in education working in Brazil (Rosemberg et al. 2003; Luca \& Miranda 2004) and theorists of studies of school materials (Choppin 2004), the article seeks to contribute to a debate that, though becoming more visible in scientific and administrative-public educational circles, is still far from gaining the attention it deserves given its importance in this field of knowledge. 


\section{A brief history of the research and data analysis}

In a context shaped by Rio de Janeiro's low indicators for educational performance, the aim of my research as part of a wider project on educational problems in the city ${ }^{2}$ is to explore in detail the production of textbooks in Brazil, particularly those used by public schools in the state and city of Rio de Janeiro.

With this research goal in mind, I examined forty-two books, mostly drawn from General History and the History of Brazil - including four supplementary teaching books, six teachers books, two geography books and a manual of sociology - published between the 1950 and 2012.

The criteria for selecting the books were based on their classroom use - in other words, all the books included in the study would have to have been effectively chosen and utilized - and those published after 1997 had to have been approved by the National Textbook Program (PNLD) based in the Ministry of Education.

It should be emphasized that the books published up to the 1980 os were mostly obtained from the personal collection of the research project coordinator and the collaborating researchers. The remainder were found among the collections of teachers, directors and students from the public education system of Rio de Janeiro, with a predominance of books published after 2000.

As a first step it is important to delineate the profiles of the authors of the books defined here as traditional (TAB) with comparison to authors of more recent works. Many of the TAB authors clearly followed in the footsteps of iconic figures of twentieth-century Brazilian historiography like João Ribeiro and Capistrano de Abreu. Hence they combined their academic activities with other intellectual enterprises such as politics and the arts (João Ribeiro, for example, was a poet and philologist). As essayists, they developed or added to mostly generic interpretations of the origins and functioning of Brazilian society (Hansen 2000).

Generally speaking, the TABs (12 books were allocated in this category in the research) contain few illustrations - especially compared with

2 The research project School Ethos: Management and Production of Quality is headed by anthropologist Yvonne Maggie at the Federal University of Rio de Janeiro (UFRJ) and funded by the Rio de Janeiro State Research Support Foundation (FAPERJ) from 2009 to 2013 and the National Scientific and Technological Development Council (CNPQ) since 2012. 
present-day books - and few bibliographic references. Their arguments are presented without much in the way of theoretical or methodological concerns.

Many of their authors had studied or worked in important educational centres in Rio de Janeiro, capital of the Republic at the time, including the Institute of Education and Pedro II College. Subsequently they themselves became a reference point for other historians and teachers from their era.

The RAB authors, for their part, were nearly all trained in undergraduate and teaching training courses at universities (the majority public) from various regions of the country (predominantly the southeast). The 51 authors identified in the publications of revisionist books had the following qualifications:

Table 01

\begin{tabular}{l|c}
\hline Highest level of qualification of RAB authors & \\
\hline Postdoctorate & 01 \\
Doctorate & 12 \\
Master's & 8 \\
Bachelor/Teaching Diploma & 26 \\
Educational level not specified & 4 \\
\hline Total & 51 \\
\hline
\end{tabular}

The majority of the authors with bachelor degrees, teaching degrees and/ or MA diplomas had careers in the primary and secondary school system, while those with doctoral and postdoctoral qualifications mostly worked at universities.

Hence we can observe that of the 51 authors identified, 25 worked in schools and 13 in universities (just two of the authors who worked in universities did not have a doctorate). The remainder did not declare their teaching activity.

While the careers of the TAB authors seem to have developed through their inclusion in the national intellectual elite (or at least state elites) with teaching experience at institutions like the Historical and Geographic Institute of São Paulo, the Federal Chamber of Deputies and Senate, and so on, the activity of the modern architects of Brazilian historiography is linked to work within a fairly specific professional-market niche, guided by 
rules on publication, evaluation and distribution consolidated by the PNLD and other directives (Luca \& Miranda 2004).

As well as analysing the authorship and content of the textbooks, semi-structured interviews and meetings were also held with primary and secondary school teachers from Rio's public school system. The secondary school teachers were chosen from the areas of History, Sociology, Geography and Philosophy, though staff from the first discipline predominated. The research also involved the participation of teachers from primary school, pedagogical coordinators and assistant directors.

The interviews and meetings were conducted with the following framework of questions: (1) the academic staff's views of how to approach the themes of Brazilianness, citizenship and otherness (the respect for differences) in the classroom; (2) the utilization (or not) of the school book as a tool in the teaching-learning relationship; and (3) the perception of teachers concerning the teaching of the History of Brazil today.

Researchers of the subject like Alain Choppin (2004) claim that when investigating the history of western science's interest in school materials, we invariably encounter two distinct methodological tendencies. The first of these, classified by the author as 'ideological,' focuses on the analysis of content where attention falls not on the book per se but on the treatment given to particular historical figures, events, polemics, political facts and so on. The central question is not "the book and its production" but "what the book discusses..." The second tendency, labelled epistemological or didactic, concerns the construction of the book as an object in the science of education. The central point is the book's capacity to foster critical reflection among its readers, adapt to specific pedagogical programs, promote knowledge building and so on. This approach focuses on the book as a 'tool.' As Choppin points out, these two dimensions are indissociable. However, it is worth emphasizing that the present research veers more towards the field defined by the first tendency.

My underlying impression is that school textbooks are the outcome of power relations that potentially express the conflict of interests between distinct social groups. They attempt to enforce the hegemony of a particular idea, or even constitute part of a State strategy to defends its legitimacy or the construction/consolidation of national sentiments (Choppin 2004). On the other hand, in symbiotic form, these materials also produce discourses, 
ideas, hegemonies and thus engender new power relations (Choppin 2004; Althusser 1985).

In the present case, my interest lies in observing how political discourse after the military dictatorship and the endeavour to affirm democracy, citizenship and respect for cultural differences - and subsequently, as we shall see, racial differences - as values began a process that I qualify as a revision of the History (and historiography) of Brazilian society and, by extension, the contents of school books.

Nonetheless, I wish to problematize - albeit rapidly given the space available here - some points in the production, evaluation, circulation and use of textbooks in Brazil, in particular those in History.

\section{An overview of textbooks in Brazil}

Authors like Luca and Miranda (2004) help shed light not only on how social representations contained in textbooks express a specific political context, but also the extent to which the processes involved in the production and distribution of textbooks also comprise an epiphenomenon of wider configurations of power.

It was in the Vargas Era (the 1930s), for example, that the first attempts were made to standardize and influence school textbooks. Government measures such as the creation of the Ministry of Education and Public Health Affairs and the issuing of Law Decree 1006/1938, which created the National Textbook Commission (CNLD) are examples.

In a political context involving the centralization of power in the hands of the State and a cultural atmosphere of promoting national identity, textbooks fell under political-ideological control, losing their didactic or methodological function in the process (Witzel 2002).

It was only in the period after the military coup d'état that the national textbook policy would once again undergo significant changes, especially through the participation of the United States Agency for International Development (USAID) in setting up the Technical Book and Textbook Commission (COLTED) in 1970 (Freitag et al. 1997).

With a plan to distribute 51 million school books in its three years of operation, the military government's policy for textbooks involved a strong technicist bias (aimed towards rapid growth in Brazil's economy), 
the dissemination of a jingoistic nationalism (exalting the fatherland and civicism) and, as Luca and Miranda (2004) argue, by an acritical and heroic interpretation of national historiography.

The next major shift in the treatment of textbooks in Brazil was during the period of re-democratization with the setting up of the Textbook Program in 1985. As a dual management program (the regulatory guidelines are established by the Ministry of Education while production and distribution was coordinated by the Student Assistance Foundation/FAE until 1997 and subsequently by the National Education Fund/FNDE), the first years of the PNLD's activities saw a huge disparity between the demand from schools and the production, evaluation and distribution of books by the Federal Government. According to the authors:

Research carried out in Brazil and sponsored by the MEC itself has indicated at distinct moments [the existence of] undeniable problems involving systematic delays in the publication and distribution of the guide for schools, all kinds of incongruences in relation to the choices made by teachers and the dispatch of works by the FNDE, delays in schools receiving the books, as well as weaknesses in terms of the use of the works sent, sometimes disdained or even ignored entirely by the teachers. (Luca \& Miranda 2004: 126)

These questions, far from negligible, have to do with the logistics of production and distribution. At the same time, though, other questions of an ideological and pedagogical kind needed to have been addressed. As Mantovani (2009) points out, the Textbook Seminar: Content and Assessment, organized in 1995 by the MEC's Primary Education Department, began a process (even though the event focused on books from Years 1 to 4 ) of systemizing the evaluation of textbook contents with the stipulation that the Federal Government could only acquire materials approved by competent bodies.

Two key issues emerged as an outcome of the Textbooks Seminar and became eliminatory criteria for the acquisition of school materials: "( 1 ) books [could not] express prejudices relating to origin, race, sex, colour, age or any other form discrimination; (2) and [could not] be outdated, or contain or lead to serious errors in relation to the area concerned, such as conceptual errors, for example" (Mantovani 2006: 43, my emphasis). 
In exploring the ideological and pedagogical dimensions of school textbooks, the seminar on evaluation guidelines highlighted concerns echoed in the works of authors like Nosella (1981, cited in Mantovani 2006:37-8)

(a) the textbook maintains stereotyped views of the family (the family shown in in the books adheres to the traditional model, formed by heterosexual parents, children and grandparents); (b) the books reproduce the ideology of the dominant classes in which class conflicts to a certain extent remain concealed or minimized; (c) in the books the school is presented as a 'second home' and not seen as a space for socialization and raising pupil awareness of rights and duties; (d) in the books obedience and conformism are seen as a virtue and a behavioural standard to be followed; (e) the books seldom explore scientific reflexivity, appealing instead to formulae that are given but never explained; and (f) the books reproduce stereotypes concerning particular sectors of the population, such as indigenous peoples, who are treated as a distant element outside the real world.

Consequently, the contribution of the authors cited above allows us to adduce that the school textbook policy developed in the period of re-democratization has the following the central points: (1) the defence of libertarian and egalitarian principles, geared towards the democratization of access to teaching materials; (2) the inclusion of teachers in the selection process, and (3) a focus on the quality of school books, conditioning private sector production on public sector approval.

Hence, the Textbook Program, since its shift towards technical evaluation, ${ }^{3}$ has been supported by the Textbook Guides which have become a kind of filter orienting the process of academic staff choosing their teaching materials using the criteria highlighted above. It should also be noted that other policy guidelines on the production and utilization of teaching books were also introduced from the mid-199os, in particular in the area of History.

3 The PNLD classifies textbooks into four categories. Excluded books - which fail to meet the minimum requirements (conceptual errors or racist, homophobic and/or sexist content, etc.); non-recommended books which present flaws in terms of contributing to a good education; books recommended with some reservations - which meet the minimum criteria in terms of quality but which require teachers to complement or adjust the content; and recommended books - which perform their desired pedagogical function, including meeting more specific criteria. In the PNLD's initial evaluation, $60.3 \%$ of the books were classified as non-recommended and around $17 \%$ were excluded. For more details, see Mantovani 2006. 
A detailed evaluation of the official documents produced by the Brazilian State via the Ministry of Education would extend beyond the scope and aims of this paper. We can cite, though, the creation of the Fund for the Maintenance and Development of Primary Education and Valorisation of Teaching (FUNDEF), which aims to improve the quality and recognition of the teaching profession; the Cash in the School Program, which seeks to encourage the independence of schools and the development of their own educational projects; policy evaluation (SAEB - Basic Education Evaluation, ENEM - National Secondary Education Exam) and the Provão (National Course Exam) which orients and supports the teaching systems towards improving quality; and TV Escola (School TV), which allows teachers from diverse parts of the country to access up-to-date information and proposals on educational practices.

Two core initiatives can be mentioned here that combine with the National Textbook Program (PNLD) to provide 'lines of approach' to questions like citizenship, democracy and respect for differences. The first is the National Curricular Parameters (Parâmetros Curriculares Nacionais: PCNs) project, institutionally defined as follows:

[...] they [the parameters] constitute a benchmark for quality education at Primary Level across the country. Their function is to guide and guarantee the coherence of investments in the educational system, sharing discussions, research and recommendations, and supporting the participation of Brazilian technical officers and teachers, especially those working in more isolated environments with less contact with the contemporary pedagogical literature. (Brazil/MEC 2007)

Set up almost simultaneously with the creation of the National Textbook Program, the PCNs can be summarized as a reference material for approaching interdisciplinary themes with primary and secondary school students. These are: Ethics, Health, Environment, Cultural Plurality and Sexual Orientation. The basic idea behind these parameters was to harmonize the work of teachers from diverse regions of the country, working in very different sociocultural contexts, with a set of ideas aimed at valorising education committed to training citizens who would be open to subjects of collective interest, aware of contemporary issues (sustainable consumption, globalization, etc.) and more disposed to respect diversity. 
The second initiative, set out in Law 10.639/03, makes teaching the History of Africa and Afro-Brazilian Culture compulsory in teaching institutions throughout the country (later amended by Law 11.645/08 to include the History of Indigenous Populations as a further compulsory element). This law emerged as a more clearly political initiative, responding to what is described as a historical demand made by movements campaigning for black rights in Brazil for revising materials that tend to produce or reproduce stigmas and preconceptions, simultaneously redefining the role of black people in national historiography through the recognition of not only the oppression experienced in the colonial context but also the struggle of black men and women in pursuit of citizenship and a dignified life, with the need to confront racial discrimination (Augusto dos Santos 2005; Sant'Anna 2001).

Specifically discussing the evaluation of History books, Luca \& Miranda (2004) indicate a gradual rise in the approval rates of the materials, which, the authors argue, is explained by the successive adaptations made by authors and editors to the parameters cited above. Market concentration, where smaller companies (and their professional workers) tend to become incorporated into a few publishing groups, has facilitated this process of adjustment to the regulatory framework established by the State.

Despite this market dynamic and an evaluation process that has had a centralizing tendency since its origin, the authors do not observe complete homogenization of teaching materials, in particular History books. Mapping the evaluation guidelines set for PNLD 2005, ${ }^{4}$ Luca \& Miranda (2004) note four central themes: "(1) how History is viewed; (2) the relation to the student's knowledge building process; (3) how the curriculum is approached, and (4) the general relation to the development of Historiography." In terms of types of orientation, the authors distinguish between those books with a procedural approach, guided by historiographic research, questioning sources, and paying special attention to the construction/legitimization of historiographic knowledge, and those with an event-based approach, adopting a more informative than critical approach, and finally those with a global approach, which

4 In this instance 28 History collections were analysed with 22 being approved and 6 excluded. For further details, see Luca \& Miranda 2004. 
continue to make use of historical information derived from socially accumulated logic, as well as the canonical areas of content, but also explores how historical knowledge is constructed, problematizes sources, and presents elements that ensure that both students and teachers are aware of the provisory dimension of historical explanation. (2004: 135)

Surveying the history books submitted to PNLD 2005, the authors indicate the predominance of event-based narratives ( $69 \%$ of the history collections presented), though this should not conceal the advances made by procedural or global approaches and their advocating of a critical and constructivist view of historiographical knowledge.

In sum, the contribution of the authors cited above converges in recognizing that analyses of school materials form a complex dimension of social research, taking into account an intricate web of actions undertaken by a wide network of agents, which include editors, authors, analysts, managers, teachers, directors and students. Hence fundamental dimensions like the economic interests of the actors involved, the power dynamics that delineate a particular textbook policy, ideological aspects promoted by the State as mainstays of its legitimacy - within a particular historical context - and the cognitive nuances of the teaching-learning relationship emphasized by any given editorial output are just some of the elements that permeate analyses of this kind of material.

The objectives of the present article are modest given the scale of the challenges involved. My aim is to examine how the notion of Brazilianness was presented in history textbooks during a period spanning from the second half of the twentieth century to the first decade of the new millennium. The intention is to analyse the impact of certain discourses consolidated during the re-democratization process, specifically ideas of nationality that had traditionally been transmitted to new generations not only through school books, but also through major rituals celebrating the nation and absorbed into popular culture. I set out, therefore, from the premise that the post-1980 re-democratization process, which included the founding of the National Textbook Program, was defined not only by the promotion of ideas like equality, citizenship and respect for the individual and collective rights of citizens at the level of politics praxis, but also by revisions to the actual 
history of the nation and a reappraisal of certain values of the present through a rewriting (or reinterpretation) of the past.

\section{Brazil and its origins: Traditional Approach Books (TAB)}

In the TABs, the Portuguese adventurer, the African slave and the autochthonous and wild Indian compose a national mythology, while simultaneously projecting various sociopersonas as protagonists in the development of social relations during Brazil's Colonial and Imperial periods.

In the 1952 edition of his Historia do Brasil, ${ }^{5}$ the historian and politician Basilio de Magalhães, ${ }^{6}$ a native of Minas Gerais state, defined the formation of the Brazilian people as follows:

Brazilian ethnicity resulted from the fusion of three elements: the xanthodermic [yellow-skinned], owner of all the vast region and occupying it uninterruptedly from south to north and east to west; the leucodermic [white-skinned], represented by the Portuguese, discoverer and colonizer, as well as other Europeans coming in small numbers and for various reasons already pointed out previously, such as the Spanish, French and Dutch; and the melanodermic [black-skinned], introduced here in huge numbers from the beginning of regular occupation until 1855 in order to, in the state of slavery, provide indisputable services to domestic life, agriculture, mining and diverse other industries.

None of the three main factors involved in the emergence of the Brazilian from the colonial period was pure or homogenous: the Portuguese were a diversely formed ethnic group as I have already had occasion to point out; the Amerindian population was also heterogeneous, formed by the Ges and

5 Magalhães (1952).

6 The historian Basílio de Magalhães was born in Minas Gerais in 1874, and died in 1957. According to the archives of the Teaching and Textbook Laboratory of the History Department of FFLCH, University of São Paulo (USP), he was a history teacher at the Institute of Education in Rio de Janeiro, and was active in politics, representing Minas Gerais as a Senator and a Federal Deputy. He was also acting director of the National Archive and Teacher in the History of Civilization at Pedro II College in the 193os. His publications included História do Brasil - $3^{\underline{a}}$ série, issued in 1945, and História do Brasil para a segunda série dos cursos clássico e científico, dated 1955, both published by Livraria Francisco Alves; História do Comercio, Industria e Agricultura, published in 1934 by Companhia Editora Nacional; Expansão Geográfica do Brasil Colonial published in 1944 by Espasa publishing house. For more information, see: http://lemad.fflch.usp.br/node/491. It should be noted that the publication date contained in the research archives (1952: see previous note) and the date of the work held at the Teaching and Textbook Laboratory of the History Department of FFLCH, University of São Paulo (USP) [1955] do not coincide. I presume that the version analysed here had yet to be included in the Laboratory's database or collection. 
the Tupis, encountered on the coast or near to it, the latter having been more inclined to accept mixing with the Whites; and the Africans brought here by their Portuguese enslavers, coming from diverse racial types from the black continent. (Magalhães 1952: 49).

Aimed at a young readership (equivalent today to the second year of secondary education), Magalhães' book emphasizes two features typical of the History textbooks defined here as traditional: the presence of the three 'founding elements' and the idea of mixture - or the 'loss of purity' - as a striking feature of the nation's birth.

The definition of Brazilians as a people capable of aggregating various cultural conditions but who are fundamentally Black, Indian and Portuguese reappears in História do Brasil (Coleção Didática F.T.D.), aimed at the fourth grade of high school, equivalent today to the ninth year of schooling) in 1957. In Chapter III, entitled 'Ethnic Formation,' we encounter the following passage:

Three races contributed to the ethnic formation of the Brazilian people: the Whites, the Blacks and the indigenous people. [...] Brazil only knew European immigrants of nationalities other than the Portuguese after proclaiming its Independence $[\ldots]$. Before this time we only encounter residues of Dutch and French elements resulting from these nations' attempts to seize control of part of our territory. These are simple residues unlikely to be a sizeable factor in our ethnic formation. (Coleção Didática, 1957:30)

The basic organizational structure of the TAB books analysed in the research covered four themes: (1) Discovery (historical background); (2) Ethnic Formation; (3) Administrative Regime of the Colony; and (4) Expansion and Defence of the Territory. Ethnic Formation can be taken as a guiding element in this approach: it is taken as the source of conditioning factors that help 'explain Brazil' from the colonial period to the proclamation of the Republic and the collapse of the slavery system. Although 'the encounter of the races' is its central element, the supposed levels of cultural and technological development of 'the three races' are taken to have delineated the later sequence of historical facts, such as they are perceived. In this view, then, the 'more advanced civilizational stage' of the Portuguese had enabled their overseas adventure, as well as the development of the country's legal, political and religious institutions, the energy for work of 
black Africans had helped sustain the economic system based one sugar cane plantations, while the native knowledge of the untamed land had enabled the fight against invasions and separatist movements. This ethnic formation, though conditioned by different 'civilizational stages,' could be successful in a configuration where 'each one has its role,' with the Portuguese assuming the role of governing the nation.

In his text "Digression: the fable of the three races," Roberto DaMatta, based on an analytic framework that highlights the contrast between the egalitarian-democratic and authoritarian-hierarchical principles evident in Brazilian society, develops a model of Brazilian social structure in which the white population occupies a privileged situation with black and indigenous people (and mestiços in general) in a subaltern position. According to DaMatta, Brazil's social stratification appears in racial terms. This fragile social arrangement is based on the idea of a complementarity, In which the conviviality between 'racial groups' is celebrated, although the cultural (civilizational) ranking between them is also reaffirmed.

This view of Brazil's social reality can be found recurrently in the TABs: the celebration of a singular mixture and the recognition of the nation's viability as a civilization. A perception that follows in the footsteps of authors like A. Ramos, Manoel Bonfim and in particular Gilberto Freyre, who, abandoning earlier racist premises concerning the moral and intellectual inferiority of non-whites, observed the racial encounter from a perspective of the cultural whole. In another sense, though, we can also still detect the shadow of racial inequality given that the contribution of the Portuguese in the prevailing discourse of the TABs - with the predominance of their language, institutions and religion - is taken to be greater.

In a new publication of his História do Brasil in 1958, Basílio de Magalhães summarizes the role of the Portuguese for the future of the nation as follows:

Indisputably the most beautiful flowering of Portugal's historical mission - to reveal the immensity of the human planet for civilization and culture - and its colonizing potential is Brazil. (Magalhães 1958: 41)

Citing authors like Silvio Romero, Roquette-Pinto and Oliveira Viana, Basílio Magalhães assesses the participation of Brazil's formative elements in the colonial economic structure as follows: 
[From the] economic viewpoint, the African played a more important role than the Indian, since it was they who essentially helped transform primitive bartering transforming into a commercial activity. In domestic life it was also the mamães-pretas [black mothers] who transmitted so many tales and so much affection to the nation's social formation. (1958: 51, my emphasis)

Returning to the Coleção Didática adopted by the Marista Brothers, we find a passage that exemplifies the arguments developed earlier:

The white man was represented by the Portuguese, who discovered and colonized the land [and who] came to constitute the most important part of the Brazilian population, transmitting his language, religion and customs [...]. The indigenous element with its inferior civilization and semi-savage customs was quickly dominated, despite the strong resistance opposing the plans of the conquistadores. The black element, originating from Africa, was introduced into Brazil to labour in the fields, replacing the indigenous people who refused to submit to the work of a sedentary life. (Coleção Didática, 1957: 62) (My emphasis)

Having coordinated the Revista de Ensino do Rio Grande do Sul for 21 years, a journal that attained a print run of 50,000 copies, circulated throughout Brazil, the primary school teacher Maria de Lourdes Gastal was the author of the book Estudos Sociais e Naturais [Social and Natural Studies], the $12^{\text {th }}$ edition of which was published in 1961.

Targeted at Year 3 of primary school, the work is divided between the areas of History and Geography with an approach focused on the occupation and demographic formation of Brazil's southern states. Hence those contents that usually appear under rubrics like 'our folk' or 'the formation of the Brazilian people,' in this work are inserted in the topic 'Influence of German and Italian Colonization.' On the Brazilian types, or rather, those of the South, we read:

[The Indians were the inhabitants encountered by Cabral when he landed here.] They were men, women and children with skin burnt by the sun and straight black hair. They walk around naked and, on festival days, adorn themselves with bird feathers, necklaces, bracelets and body painting. [...] Most of Brazil's tribes have today been pacified and have a friendly relationship with civilized 
folk, thanks to Marshal Rondon who devoted his entire life to defending the Indians. (Gastal 1961: 17-8)

Germans, Italians and their cultural contribution to the southern region are described thus:

To develop agriculture in Rio Grande do Sul, the government allowed German colonists to come. They populated the forests, built roads, developed agriculture, began and developed various industries. Orderly, good heads of family, Christian and hard-working, the Germans transmitted these qualities to their descendants who have, moreover, an exemplary family education.

As well as German colonization, Rio Grande do Sul also took in Italian colonists. These devoted themselves especially to viniculture and winemaking [...] Highly dedicated to work, fervent Christians and, for this very reason, good heads of family, a happy spirit, communicative, fine musicians and singers, the Italians transmitted these qualities to their descendants. (1961: 88)

On the supposed predominance of one culture over the others (or, read without the culturalist anachronism, the dominance of one 'race' over the others), the arguments of the lawyer, politician and historian Brasil Bandecchi (a member of the Historical and Geographic Institute of São Paulo) are among the most contradictory. At the same time as he recognizes the superiority of European civilization, he categorically asserts the equality of the contributions of Blacks, Indians and Portuguese. He writes:

When it came to the composition of the Brazilian people, whether due to their much higher numbers or more advanced civilization, European culture ended up prevailing. This culture would stand out more. Much more. Nonetheless, the Blacks left very clear traces, meaning that they really stood out. The Indian influence was much less. (...) It cannot be said that one culture dominated the other, but that there was a sum of positive factors in the formation of our people. (Bandecchi 1973: 89) (My italics)

This type of contradiction is found in other examples. While the superiority of one culture/'race' over another is affirmed - normally registered as technological development or 'moral eminence' - the texts recognize that all are equal and all have played a fundamental role in the nation's development. 
In the Enciclopédia Ilustrada para Educação Básica ('Illustrated Encyclopaedia for Primary Education') by Jose Abila Filho, published in 1977, we encounter a description of how Brazilian culture was formed that is very similar to Brasil Bandecchi's version. The entry 'Ethnic Elements' states:

Blacks: Their participation in the Brazilian economy was greater than that of the silvicolas ['forest dwellers': indigenous peoples]. They represent the main workforce in the national economy due to their knowledge of agricultural, mining and metallurgy, as well as the facility that they showed for learning. From them we inherited religion and cuisine.

Whites: (...) [through the influx of migrants] brought more advanced technical knowledge and more complex life habits, and represented a human capital that eventually consolidated [Brazil's] population. (Abila Filho 1977: 142) (My emphasis)

The remarks on indigenous culture appear in a separate entry:

\section{Possessing a very backward culture, Brazilian Indians live in various}

groups. They are differentiated among themselves by language, tradition and physiognomy. [...] Initially good friends to the Portuguese, providing valuable services through enslavement, they then revolted, constantly attacking the [mission] villages and plantations since they were unaccustomed to work. (1977: 156) (My emphasis)

A specific entry of the Encyclopaedia describes the 'interbreeding' between Indians and other 'races,' called 'Brasilíndios':

those who appear in the towns almost always bring with them two stigmas of our civilization, the vice of drunkenness and syphilis. Their favourite pastimes are festivals and dancing. (1977: 200)

Once again an initial reading suggests a dismissal of the cultural contribution made by Brazil's black and indigenous populations. However, José Abila Filho's work also contains a recognition of the 'cultural whole' achieved by miscegenation. Concerning the Portuguese, the author tells us:

[...] from them we received a priceless legacy: the language that we speak, the bases of western culture, Catholicism [...] they taught us not to differentiate 


\section{between the races, showing that all are equal, by interbreeding with the Indians and Blacks, producing large-scale miscegenation. (1977: 210)}

But the idea of a whole is only possible thanks to the harmonization and reconciliation of Brazil's 'formative elements.' Consequently the conflicts inherent to slavery, catechism and acculturation are downplayed in traditional books in favour of promoting an ideal of conformity that over more recent decades has been denounced by black activists as a false sense of cordiality (Guimarães 2002, Hanchard 2001).

One of the most striking features of the TABs, then, is the apprehension of Brazilian society during the colonial and imperial periods as a harmonious composition in which each racial group made its own contribution, with the Portuguese responsible for guiding the nation along its civilizational path. In this view, sexual contact functions as a 'trimmer,' shaping the formative elements - self-contained in their cultural specificities - into a single whole: the Brazilian.

The idea of a racial-cultural amalgam transmutes into the idea of the nation and thus the notion of the fatherland. In his supplementary teaching book Eles fizeram a história do Brasil ('They made the history of Brazil'), published in 1963, the author Roberto Macedo provides a fictional account in which historical characters are interviewed by a boy, Rebedeco, a pupil who the night before a school exam begins to dream of these legendary figures who recount their deeds for the nation.

After meeting Cristopher Columbus and Pedro Álvares Cabral in his dreams, the boy encounters the chief Temininó Araribóia. He tells him about his heroic role, alongside the Portuguese, in expelling the French from Guanabara Bay. Presenting himself as a kind of guardian of indigenous lands, 'legitimately conquered' by participating in the attack on the French invaders, Araribóia recounts his epic tale to Rebedeco, reaffirming the role of Indians as allies in the defence of Portuguese sovereignty over Brazil.

As depicted by the TABs, black and indigenous people can form a vital part of the Portuguese civilizational framework through a shared sense of communion. Catechism is portrayed in the book by the image of a thankful and docile Indian (Paranaguaçu) at the feet of the Jesuit José de Anchieta, under the watchful eye of Rebedeco:

In the book the figure is accompanied by a caption that gives voice to the Indian Paranaguaçu. He says: "and now I know how good you are, I shall end 
this war against the Tamoios - the kneeling Paranaguaçu confessed emotionally." (Macedo 1963: 29). The wars against the European 'invaders' are treated as a question for all Brazilians, here equalling BLACKS + INDIANS + PORTUGUESE. The amalgam, which is both genetic and cultural, as defined by the TABs, is presented in Macedo's book as a national issue.

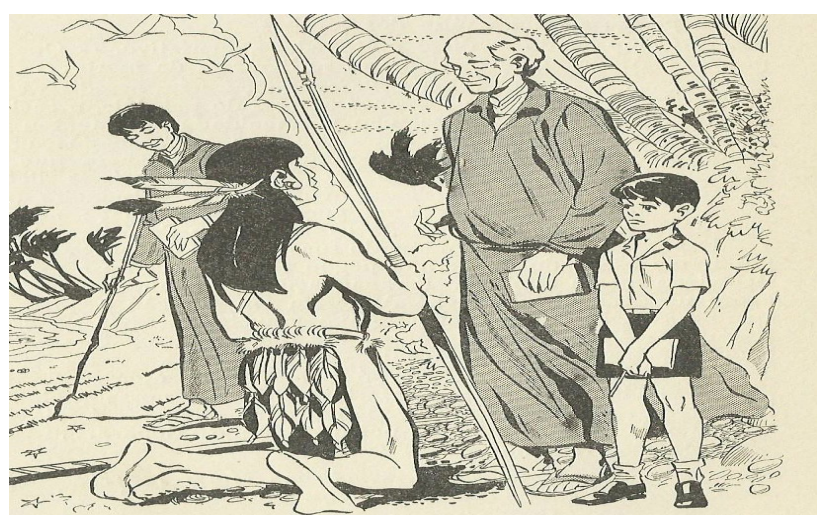

Discussing the expulsion of the Dutch from Pernambuco, the author, through the voice of the governor of Pernambuco, Matias de Albuquerque, conjectures: “...there for the first time, Whites, Indians and Blacks fought side-by-side against an invader of Brazilian territory. There was already, therefore, the feeling of defending the Fatherland" (Macedo 1963: 76). This rhetorical pattern continues unaltered until we reach the material produced in the mid-19gos when a shift is perceptible in the discourse concerning the (con)forming of the Brazilian people. Now, the contradictions inherent to the relations of domination between colonizers, natives and slaves are emphasized and miscegenation loses its force as a social phenomenon capable of projecting the sociopersonas of the nation's birth beyond conflicts.

\section{Revisionist Approach Books (RABs) or reinterpreting Brazil}

One of the key features of the books defined here as revisionist is their trenchant critique of the ideas of racial harmony evident in traditional approaches. In these textbooks, Brazil is depicted as a country that lives contradictorily with an ideal of integration and empirical evidence of inequality, 
a theme that predominates in revisionist approaches. In the book Historia e Consciência do Brasil ('History and Awareness of Brazil,' Secondary Education) by Gilberto Cotrim, first published in 1994, Brazil's racial mixture is defined in the section 'The Myth of Racial Democracy: the imposition of the cultural patterns of the Europeans (Chapter V)':

Taking the implications of racial miscegenation much too far, some authors like Gilberto Freyre (...) concluded that Brazil was the setting for a true racial democracy. (...) But in reality this harmonization never occurred, since the relations of domination between metropolis and colony were not limited to the economic sector, they also extended to the sociocultural dimension. The European colonizers, enabled by their political-economic control, imposed European cultural patterns on Brazil. They entirely scorned the cultural legacies of the Indians and the Blacks, considering them the contributions of inferior classes. However many cultural elements of the Indians and the Blacks were perpetuated in Brazilian life since they became incorporated into the customs of the people, without the consent of the dominant class, whose objective was solely to Europeanize the Colony. (Cotrim 1994: 66) (My emphasis)

Citing the book História do Brasil Colonial, by Luiz Roberto Lopes, published in 1981, G. Cotrim gives us the following passage:

The Blacks and the Indians were forced to adopt these norms and values due to the state of submission in which they were held. Subject to physical and cultural violence, blacks and Indians saw their patterns of behaviour and existence demeaned and even destroyed. (Lopes 1981: 20 apud Cotrim1994: 66) (My emphasis)

In this sense, the idea of a cultural amalgam is replaced by the denunciation of the domination imposed by the European colonizers. In the book Geografia Geral e do Brasil (Secondary Education), by João Moreira and Eustáquio Sene, published in 2004, in the chapter 'The Brazilian population,' we encounter another example of how the nation's 'year zero' was interpreted by the RABs:

From 1500, native ethnic groups began to suffer genocide (physical extermination) or ethnocide (the destruction of their own culture: they began 
to speak another language, to profess a new religion, they changed their dress and their food, in other words, they became part of the colonizers' society).

(Moreira \& Sene 2004: 448)

In Chapter II, 'The Europeans Arrive,' of Trilhos e Trilhas ('Tracks and Trails,' Fourth Grade History, Second Edition, Teacher's Manual), published in 2004, the authors Maria Salvadori and Jane Fernandes explore the theme through the idea of a 'meeting of differences' and, subsequently, of the difficulties of resolving these differences over time. In the section 'The Indians in today's Brazil,' they write:

Of the many indigenous groups who inhabited Brazil, few remain today. For the vast majority of these groups, contact with the 'whites' over these more than 500 years has been alarming. Many Indians have been dominated, others have been killed in the fight to ensure their freedom and their rights... (Salvadori \& Fernandes 2006: 34)

The reading exercise concludes with the presentation of the 'Case of the Indian Galdino,' quoting a report from the newspaper O Estado de São Paulo, dated April 1997. The text reads:

Brasilia - The Pataxó Hã-Hã-Hãe Indian Galdino Jesus dos Santos was burnt alive yesterday by five middle class youths. He was sleeping at a bus stop when at around 5.30 am a Monza pulled up next to him. The youths threw a liquid over his body [...] and set fire to him. Rescued, Santos arrived conscious at the Asa Norte Regional Hospital (HRAN) but the doctors saw no chance for his survival. (2006:34)

The treatment given to Brazilian Blacks is fairly similar. Images from the past show the harshness of plantation work. Emphasis is given (in Chapters III and IV) to the resistance strategies represented by capoeira (a balletic martial art of African origin), quilombo (maroon) communities and Afro-Brazilian religion. The conflicts of the past find themselves actualized in the present, not as a kind of echo that has gradually drained in strength but primarily as a practice that is reproduced through diverse forms of prejudice and racial discrimination. The arguments are illustrated with a report published in Veja magazine on 7 February 1996: 
The routine humiliation of middle class black people exposes the [disguised] racism in Brazil. In Brazilian racial democracy, an optimistic idea sustained by romantic anthropologists, the black person who rises socially is destined to discover a more subtle face of discrimination. As an example: many police officers regularly pull over black men driving luxury cars [...]. While in the case of the police, this racism is explicit, in other situations it is more subtle, though no less painful. The Bahian entrepreneur Luis Carlos Reina, owner of assets worth two million reais, proved that it is not enough to be rich to be free of such annoyances. At the end of 1994, he made a telephone purchase, from Salvador, of a Mustang Coupe car from a dealership in São Paulo. He was called 'doctor' [a recognition of social status] on the phone and made a $\mathrm{R} \$ 58,000$ down payment. When he arrived to fetch the vehicle he was rudely treated by the receptionist who refused to call the car salesman. 'So fetch me the manager,' Reina said impatiently. 'It's impossible to find him,' the woman replied. The quarrel continued until the entrepreneur identified himself as the buyer of the Mustang. 'Within a few seconds everyone appeared,' he recalled. 'Black people are treated with intolerance in Brazil. When you have money, you get called doctor, but you're always seen as the exception,' Reina laments. (1996: 66) (My emphasis)

The book O Racismo na História do Brasil [Racism in the History of Brazil], an extra-class book published in 1996, written by the historian Maria Luiza Tucci Carneiro, exemplifies this questioning the ideas of harmonization promoted by the TABs, along with the search to comprehend the inequalities of the present through the reproduction of the oppressions of the past. The forms of learning and teaching the History of Brazil are also thrown into question.

\section{The Imagined Brazil}

Brazil always sought to project the image of a cordial nation, inhabited by a peaceful people without preconceptions of race and religion. For years we nourished the idea that we live in a true racial democracy, despite the visible inequities and limited opportunities offered to black, mixed, indigenous and Roma people. It always suited the white population to maintain the myth that Brazil is a racial paradise, as a form of absorbing 
social tensions and masking the mechanisms used to exploit or subordinate the other and the different.

But does this racial paradise really exist?

Look around you. How do people live, where do Brazil's white, black, mixed and indigenous peoples work? To which racial group do most street kids belong? How many doctors, university professors, priests, engineers, bank managers, military officers, industrial executives, politicians or TV presenters do you know who are black, mixed or indigenous? [...]

And the Jews? Have you ever heard anything about them? Do you have even a vague memory of having studied that, during the colonial period, the State and the Catholic Church persecuted all those descended from Jews? (Tucci Carneiro 1996: 5) (My emphasis)

To varying degrees, all the RABs exhibited a discourse in favour of difference that appears to replace or overlap - in contradictory fashion - the earlier discourse celebrating mixture. Especially, though not exclusively, in the books intended for the first grades, we can observe the valorisation of 'cultural specificities.' While in the TABs we find a celebration of fusion - creolization to use the term proposed by theorists of ethnicization like T.H. Eriksen (2007, apud Hofbauer 2009) - in the RABs we can note the authors' enthusiasm for how different cultures can live together, not infrequently presented in terms of 'race'/ethnic groups. In História: Viver e Aprender ('History: Live and Learn,' Year 2), published in 2004, Elian Lucci and Anselmo Branco argue:

Boy, girl, tall, fat, thin, white, black, yellow, Brazilian, African, Chinese, German... whatever their sex, religion or nationality, children are children all over the world! Even so, no child is like any other. Everyone has his/her particularities and ways of being. (Lucci \& Branco 2008: 18) (My emphasis)

In Histórias, Tantas Histórias ('Histories, So Many Histories') from 2008, also a Year 2 book, Ana Luísa Lins teaches:

People may have some things in common: they may prefer the same kind of music, have the same opinion about a subject, like the same games, but in other aspects they are different. Only there are some people who refuse 


\section{to accept those with another skin colour, another religion, other tastes.}

(Lins 2008: 17-8) (My emphasis)

In História (Coleção Conviver) ('History [Living Together Collection],' Year 2), first published in 2009, Ricardo Dreguer and Cássia Marconi include various examples of diversity in the first sections of the book, associated with kinds of play, rules of socialization and family structure, forms of celebration and work organization. The authors' intention is very clear: to tell students that beyond their own personal experiences, other forms of organizing reality exist that are just as legitimate. On 'kinds of games,' in the section 'Indigenous play,' the authors state:

From an early age, the young Indians learn about nature and, making use of it, make simple instruments with which they can play. They make bows and arrows, straw animals, clay or corn dolls, little wooden or assai palm straw canoes, spinning tops, shuttlecocks and various toys made from palm coconuts and straw. (Munduruku 2000 apud Dreguer \& Marconi 2009: 13)

'Indigenous childhood' is presented through a relationship with nature and by the 'simplicity' and spontaneity of daily life. The way indigenous children relate to objects and to other children is presented in terms of the specificities of their culture. The message contained in recent textbooks is that 'in their own way' indigenous children also experience childhood as a life stage marked by the close ties with their parents, discoveries and the need for freedom. Childhood is presented as something universal but experienced differently according to the culture. In the book História (Coleção Curumim) ('History [Curumim Collection],' Year 2) by Ernesta Zamboni and Sônia Castellar, first published in 2004, we encounter further examples. The first chapter, entitled 'The history of children,' opens with the following passage:

Did you know that, just as there is a history of different peoples, arts and sciences, so there is a history of children? Children are important in most cultures. Among each people and in various eras, there are differences in ways of living. To know how the children of various peoples lived in the past, like indigenous peoples, Europeans, Asians and Americans, among others, the historians have researched their history. So, they learnt how they were educated, what their relationship with adults was like, how they played, what they ate and how they dressed. (Zamboni \& Castellar 2004: 8) 
In this same chapter we find the section 'Indigenous Children' and the following passage:

Children occupy a privileged space in indigenous society. From the moment they are born, they are shown considerable affection [...]. Children still being breastfed are always close to their mothers. When they cry they are immediately hugged and soon put on the breast to feed. They are carried either in a basket or a kind of sling, which may also function as a crib. When they start walking, infants begin to play with other children living nearby them. They are never out of sight of their mother or leave the village. On the contrary, if the mother goes to the swidden, she takes her child with her; if she goes to bather in the river, the baby will be there too. (ibid: 13-14)

Once again the universal and specific interweave within the same pedagogy teaching the value of differences. Family structure may also be explored in terms of its specificity. Going back to the book by Dreguer and Marconi (2009), the quilombola family is defined as one with a strong connection to traditions transmitted by the ancestors, in this case, originating from Africa. The figure presented by the book is the fisherman Seu Ilário from the Jaó community in São Paulo state.

Below is a fragment of the text of the section 'The ancestors':

Figure 2

\section{Os antepassados}

As pessoas da familia que viveram antes de nós são os nossos antepassados.

O senhor llário, morador da comunidade de Jaó, localizada no estado de São Paulo, conta a história dos seus antepassados.

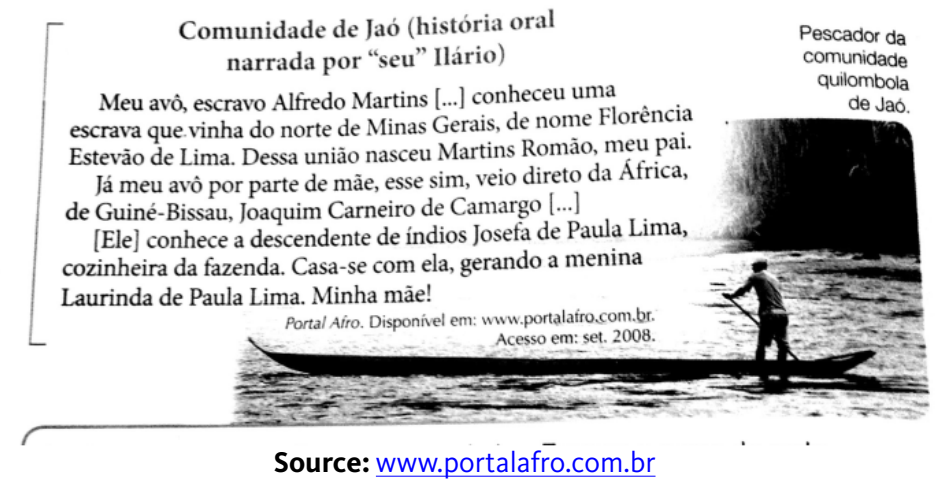


In tracing his ancestry, Ilário reconstructs a narrative involving miscegenation: his grandfather, coming directly from Guinea-Bissau, encounters a woman descended from Indians, Josefa, with whom he sires Laurinda, his mother. This passage, which could be included as an element typical to the traditional books, here takes a particular turn. While in the TABs miscegenation is presented as a core element of Brazilianness, Ilário is presented as a quilombola, an Afrodescendant citizen with ancestral connections that make him a bearer of specific customs and traditions. Next comes the passage: "Some quilombola families maintain certain traditions of their ancestors. One of these traditions is the jongo in which people sing and dance to the sounds of barrel drums, cuíca drums and rattles" (Dreguer and Marconi 2009:39)

As I have looked to argue previously, the separation of teaching materials (especially those used to teach the History of Brazil) - of the kind analysed here - into a traditional approach and a revisionist approach is a methodological resource that, at an empirical level, should not be taken as representing irreconcilable opposites. Even today many of the books taken to be revisionist tell the origin narrative of Brazilianness based on the union of the three formative elements with miscegenation as the backdrop to the nation's social and cultural development. However, while in the TABs the narratives continually refer to the idea of fusion (genetic and cultural) that eventually results in the 'Brazilian people,' in the RABs there is a celebration of differences, as though each of the formative elements of our mythic narrative of Brazilianness had, in a certain sense, remained confined within particular traditions that connect each citizen to their 'origins.'

One of the missions of education, therefore, would be precisely to teach younger people how to deal with this mosaic of differences that are often taken in cultural/ethnic-racial terms. The book História (Coleção Buriti) ['History (Buriti Collection),' Teacher's Manual, Year 2, published in 2007)], which opens with the chapter 'Everyone has their own way,' provides as a reading suggestion the analysis of a poem by the children's writer Tatiana Belinky called 'Diversity.' This synthesizes the precepts of child sociability encountered in the revisionist books. The verse reads: 
Diversity

One is nimble

Another is slow

One is pale-skinned

Another is freckled

One is calm

Another is skittish

One is whiny

Another is charming

One is lazy

Another lively

One is talkative

Another is silent

Each to their own

And it does no harm

Di-ver-si-ty

It's cool!

Beyond the demarcation of two distinct approaches on Brazilianness, citizenship and the treatment of otherness in the textbooks, we also need to focus attention on the potential reasons behind the transition from one kind of discursive construct to the other. Certainly, as Choppin, Reis, Luca and Miranda all indicate, it is no easy task to determine the factors that explain the predominance of a specific discourse in the school materials, since these are always conditioned by historical, political, social and cultural contextualizations that render any such enterprise extremely complex. I shall concentrate, therefore, on a specific field: the conjugation between the knowledge developed by the social sciences in Brazil and the narrative formulations of Brazilianness found in the textbooks. The premise is that, sometimes more directly, sometimes more subtly, the 'truths' espoused by Brazilian social thought are presented as a benchmark for school textbooks, in particular those describing the history of national representations of Brazilianness and the ideas of democracy, citizenship and equality. 


\section{Historiography and Brazilian social thought}

An early landmark in Brazilian historiography was the work of the German botanist and essayist Karl von Martius, published in his monograph Como se deve escrever a História do Brasil ("How the History of Brazil should be written'), where the author founds the idea of a 'meeting between races' as a central element in the narrative of Brazilianness (Maggie 2005).

Von Martius's approach, which represented a rupture with the historiographic trend seen during the Empire period - as encapsulated in the documentary and heroic-elitist narratives contained in Varnhagen's work - was only taken up again in the first years of the twentieth century with the publication of works by João Ribeiro (História do Brasil [1900-1]) and Capistrano de Abreu (Capitulos de História Colonial [1907]) (Reis 2007). Followers of German Kulturgeschichte, Capistrano and João Ribeiro included popular everyday life in their narratives, replacing a documentary model with an ethnographic approach. In this sense, the description of the culture of 'our formative elements' (the indigenous elements, in particular, in Capistrano's work) becomes a core component of these authors' analyses and consequently the school materials for teaching History produced in Brazil.

The inclination to valorise 'popular types,' however, was not enough for the echoes of nineteenth century scientific racism to simply vanish from interpretations of the country's social relations in the post-abolition world of the Brazilian Republic. It was only when explanations of social phenomena shifted away from biological determinism to the sociological domain, utilizing the same principles still used today, that the relations between Brazil's 'formative groups' began to be understood in political terms (recognizing the oppression and violence of the past) and sociocultural terms (optimism concerning the idea of assimilation and fusion of customs and behaviours).

The premise that the conflicts and resentments of the past could be overcome through a 'flexibility of spirits' and the inexorability of mixture, making the Brazilian case a unique experience of nation-ness structured through a racial-cultural amalgam, is today denounced as a lie. Reconstructing the critique of racial democracy takes us back to the consolidation of Brazilian sociology in the 1950 s when a research agenda was developed, under the sponsorship of UNESCO, to map the specific relations between 'colour groups' in Brazil. In a world still traumatized by Nazism, 
Brazil after the Second World War was internationally perceived as a successful case of racial coexistence.

The absence of clear racial dividing lines - like those observed in the United States and South Africa - combined with the dissemination of a scientific discourse that highlighted the exceptionality of the Brazilian situation - Casa Grande e Senzala by Gilberto Freyre is typically recalled as the classical synthesis of this thought (Chor Maio 1999) - turned Brazil into an example worthy of study. Initially planned to cover the state of Bahia only, the UNESCO research ended up expanding to state capitals in the Southeast, Northeast and North. However, it was the findings of the studies in São Paulo - conducted by Florestan Fernandes and Roger Bastide - and in Rio de Janeiro - conducted by L. A. Costa Pinto - which revealed new aspects to 'colour relations' in Brazil. The limits imposed on the integration of the descendants of slaves in the capitalist-competitive system revealed a Brazil that, around the mid twentieth century, was still shackled by racial oppression. Poor living conditions, low income and schooling, exposure to infant mortality and limited access to the labour market are some of the questions that began to feature in the debates and studies of race relations during the period. While the studies directed by Florestan Fernandes and Bastide concluded that overcoming patrimonialist and personalist practices and mindsets would almost automatically help eradicate colour discrimination, Costa Pinto's work observes the reproduction of racism as a resource that could be exploited to intensify competition between black and white populations within the capitalist system. In the author's view, therefore, Brazil's development as an industrial and urban society not only failed to cool down racial tensions, it actually tended to make them worse.

The UNESCO project's conclusions prompted a shift in Brazilian sociological discourse. Conflicts, tensions and inequality became central issues in the production of the social sciences, and the nation, once presented as 'integrated' by syncretism and miscegenation, was now able to be seen as fragmented by tensions and disputes between groups - including apprehended through the prism of racial identities - driven by divergent interests. The arguments presented in the book Discriminação e Desigualdades Raciais no Brasil ('Racial Discrimination and Inequalities in Brazil'), published in 1979 and written by the sociologist Carlos Hasenbalg, presents a minute decomposition of the socioeconomic situation of Brazilians in 
racial terms, operating with the opposition: the social situation of brancos (whites) versus the social situation of não brancos, i.e. all those who did not define themselves as white to the census takers.

The tensions revealed by the UNESCO Project researchers who conducted their studies in the large urban centres - in particular L. A. Costa Pinto - and subsequently dissected in statistical terms by $\mathrm{C}$. Hasenbalg elicited a new configuration of the relationship between the formative elements of Brazilianness and the very idea of nation-ness. Firstly the notion of 'integration' gave way to the notion of conflict. The disputes and oppressions of the past were identified in the present, teaching Brazilians that they have not only failed to move beyond yesterday's conflicts but, on the contrary, that they are living through tensions that are actualizations of the former conflicts in new social contexts.

As the historian C.G. Mota (1990) summarizes, the idea of 'Brazilian culture' forming the basis of the modernism and nationalism of the 1930s, imbued with a patrimonialist and hierarchical air, could not be fully incorporated into the principles advocated by a 'Republican culture' and its ideals of equality and the guarantee of individual citizen rights. For subaltern groups, in the Brazilian case, even after the Republic, citizenship had been limited to a prospect for the future.

To understand how Brazilian history was rewritten in light of the 1950 s sociological literature is to understand how this discourse became the official narrative of race relations and the mainstay for a variety of human rights policies in Brazil - something which can be observed from the first government of President Fernando Henrique Cardoso (FHC) (1995-2002) and continued during President Lula's two terms of office (2003-2011).

Diverse government actions confirm the 'victory' of this sociological discourse contesting 'racial accommodation.' This period is marked by the Federal Government's formal recognition of the existence and persistence of racism in Brazilian society, along with the creation of the Inter-Ministerial Working Group (GTI) to valorise the black population and the Working Group for Eliminating Discrimination in Employment and Occupation (GTDEO).

At international level, we can highlight the participation of Brazil's representatives at the Third World Conference Against Racism, held in Durban, South Africa, in 2001. At this event the Brazilian government committed to 
implementing policies for combating racial discrimination and, above all, actions intended to reduce the social and economic inequalities between the white and black populations. In the words of Marcos Chor Maio and Simone Monteiro (2005: 439):

[The Durban Conference] helped shape an anti-racist agenda racialized by social movements, sectors of academia and the media, state and multilateral agencies, and US philanthropic foundations. It is a precise indicator of how national agendas are defined in international arenas. The 'Durban effect' soon made itself felt, whether through the adoption of racial quotas in higher education, or through the implementation of racial policies in the work area, healthcare and the farming sector, under the aegis of Human Rights and social justice.

These initiatives also reflect the openness shown by the FHC and Lula governments to social movements in the operational frameworks of the State. Continuing a process already observed at state and municipal level since the 1980s, therefore, the Federal Government - through the creation of agencies like the Special Office for Policies Promoting Racial Equality (SEPPIR) and the Office of Continued Education, Literacy and Diversity (SECAD), run by the Ministry of Education and Culture, and forums like the National Conference of Policies for Promoting Racial Equality (CONAPIR), held in 2005 - has deepened the relation between more structured sectors of black social movements (and other ethnic sectors) and executive spheres of the State.

As Antônio Sérgio Guimarães (2002) observes, the discourse questioning Brazilian racial democracy became central to the black movements as early as the 1970s, propelled too by the internationalization of the 'US black question' and the pan-Africanist movement. Hence the post-1950 discourse of sociology primarily became a key line of argument for the activists, who with the increased political openness ended up migrating asystematically and seasonally, it is true - to work for government bodies (Monteiro 2010). As well as reflecting the influence of new approaches coming from a specific scientific field, namely the sociology of the 1950s, therefore, the transition from the TABs to the RABs should also be comprehended as the instrumentalization of certain ideas through the strategic positioning of particular actors in the relationship between social 
movements and the State. However, the present modest contribution can only be taken as complete if we turn to examine the everyday use of these teaching materials and the impact of these sociological 'truths' in the classroom.

\section{Rewriting History and its impasses: the view of the teachers (Final Considerations)}

The brief reconstruction provided here of the institutional trajectory of school books in Brazil, though referring to some aspects of Brazil's political setting - like the 'opening' to social movements during the postdictatorship era - and transiting through the 'ideological' dimensions of the materials (Choppin 2004), demands an examination of how they are used in everyday school life. Since the need to cover this aspect emerged during the research, I stress that the conclusions concerning the teachers' ideas on the uses and possibilities of the textbooks are even more modest and provisional than the conclusions obtained from an analysis of the same.

The first important aspect to be highlighted is that despite the expansion of the textbook program observed from the 1990s onward, many teachers remained reticent concerning their use. In other words, it became apparent that many did not recognize the works approved by the State as 'the best way' of building the critical knowledge of their pupils through the study of History (and of the associated disciplines analysed here).

During my first informal interview for the research, conducted with a Sociology teacher from a state school in the municipality of Itaboraí, I noted that access to the library was restricted. The books were locked away most of the time and, at the time, I could not fail to recall how familiar this scene was for me from my primary education days in municipal schools in Rio de Janeiro. Access to books was still a problem today!

The contents themselves can always be adapted in a bricolage of authorized books, texts produced by the teachers in the classroom, texts from the internet, unauthorized contents and so on. As an example, I quote a Sociology teacher from a secondary school in Baixada Fluminense on the outskirts of Rio de Janeiro: 
For those who have the book, I work with the book. For example, there might be a particular point that I'm going to develop in class; 'such-andsuch' chapter, page 10. Only I won't just work with the book, because not everyone has the book. That means I have to put the topics that I'm going to cover on the blackboard. In other words, I'm going to write, I'm going to change the definition, I write it up on the blackboard, so I'm adapting the text. Of course, you're limited because time is limited, since sociology for Year 1 and 2 is just a 40 or 50 minute period, depending on the school. So what happens? I have to write on the blackboard, put up the definition or point that I want to make, without being able to work with the book with everyone. When, for example, I want them to do an exercise that's contained in the book, what can I do? I have to make photocopies of the text that I want to cover, tell them to do the work at home and distribute the copies to those without the book. You lose a lot of time because of this. It increases your workload and even the costs because there aren't books for everyone. In Baixada, that's what I did: I didn't hand out the book because [there were just] eight books for sixty students, there was no way for me to do so.

A teacher from the first grades of a school from the Senador Camará district (West Zone) confirms this tendency:

I use the internet all the time. Because the internet is a television onto the world. You can find any topic there. Indeed the [pupils] are the ones that teach me. Because I don't know how to use it that well. And they're really interested because it's something that is happening at the same time. It's something that's developing at the same time as the class. I also like to use books. But alongside other media. Music, after-school activities, newspapers.

Just the book alone doesn't work. (My emphasis)

The teachers were emphatic when it came to describing the students' relation to the teaching materials. They observed that the students often pay more attention to information obtained via the internet or television. In line with modern pedagogical guidelines, the teachers tended to work with students on questions concerning their everyday life, trying to stimulate critical reflections on the reality about them. In this context, issues like a lack of enthusiasm for studying, the lack of perspective concerning 
the future (in particular in relation to work opportunities), frustration over being unable to buy consumer goods, the fascination about improving their social standing through the arts and sports, the disdain for topics of collective interest (in particular in relation to political activity) and the focus on the issue of urban violence were all recurrent topics in the interviews and reflection groups organized over the course of the research.

Summarizing their perceptions of the relationship between teachers coming from peripheral districts with students socialized in similar realities, one primary school teacher from the Complexo da Maré district remarked:

Interviewee: Look... teachers with a working class background are... and aren't... Because it's different. When they become trained teachers, they don't enrol their own children in the public schools where they work. They already belong to a slightly higher class. And when we have a teacher in the community who lives in the favela, we can see that she really does have a different way of working. People also perceive the teacher differently. She is not usual. First the teachers cannot accept that someone can live in that place because it's 'horrible.' So they say: 'Ah, but students don't think about school!' But the school also doesn't think about students. We also don't live with the students, sharing the situation that they inhabit. There's no way we can. There's a lot of poverty there. A poverty such that anyone who achieves a minimum of dignity and a minimum of wealth, the first thing they do is leave.

The difficulties of an everyday world of few opportunities are highlighted by this teacher, who detects the desire and the need among her colleagues to produce or emphasize a few 'emblematic cases' of success. These cases basically involve the students adoption of a lifestyle or worldview that do not coincide with the reality of the poorest areas. Their success appears associated with the life of the middle classes, in contrast to the world of the favelas and the urban periphery.

In this sense, social inequality seems like a larger problem than the question of differences. The teachers identify most of their students as black (preto) and brown (pardo). As a rule, the pupils identify themselves as mestiços (mixed) or emphasize that there are no effectively 'pure' types 
in Brazil, reaffirming the discourse of mixture. ${ }^{7}$ In their reasoning, racism and intolerance are indeed a problem, but not the only or even largest barrier to be overcome in their pursuit of education and social improvement - still taken as synonymous by my interlocutors during the research. Below I cite a short excerpt from an interview with a Sociology teacher from a secondary school in Copacabana (in the wealthier South Zone), also studying for a doctorate in Anthropology:

Interviewer: I think there has been [a] shift towards questions of diversity and culture. And effectively a kind of drifting away from the question of the worker. When I was young, all inequalities were explained as class inequalities, everything [was] a question of the bourgeoisie and the proletariat. It seems that one discussion is superseding the other, how do you see it?

Interviewee: Do you want to know how I cover this question at school, or how I myself see it?

Interviewer: How do you see it? And how do you cover it in class?

Interviewee: Look, I think that where Brazil is concerned, the issues are inseparable. You can't think about the racial question without thinking about the class question. I know that this is stoking the flames when it comes to discussing race relations. It's clear that if you take the base of the social pyramid, the questions aren't the same for men. So it's a gender issue too. A black male from the working class isn't going to be treated in the same way by society as a working class white male, and this applies to any question of gender. So it's difficult to think of inequality without thinking of these three elements.

$7 \quad$ Studies of race relations show a systematic difficulty in classifying Brazilians in polarized distinctions like 'Caucasian' versus 'Afrodescendant.' Racial classification is typically taken as taboo. Classifying people according to their colour (especially darker-skinned people) provokes some discomfort among Brazilians and, respecting this etiquette, I did not ask my interviewees to classify themselves racially. However, the course of the conversations tended towards this question. Of the twenty people interviewed individually, therefore, two classified themselves as black, four as white and the rest preferred to include themselves in intermediate categories or did not classify themselves. Although the research included the involvement of interlocutors with paler skin, phrases of the kind "I don't consider myself white" were commonplace. For a more detailed exploration of the question, see Oracy Nogueira in "Preconceito racial de marca e preconceito racial de origem: sugestão de um quadro de referência para a interpretação do material sobre relações raciais no Brasil," Revista Anhembi. São Paulo, April 1955. 
Interviewer: And what about the students, do they perceive this easily?

Interviewee: Yes. They observe that Brazilian society is heavily racist, because when I begin to cover race relations, I ask: does racism exist in Brazilian society? Almost everyone agrees. So before I get to the question of social relations, I cover the concepts of prejudice, discrimination and stereotypes. Before getting to the question, so they'll already... and so I cover different kinds of prejudices, issues of race relations, and gender relations. But yes! They understand that racism exists, but I think that this discussion about class isn't the same for them as it is for us. For them the difference is between rich and poor. Translating it a little. (My emphasis)

A History teacher from a secondary school in São João do Meriti adds further to this line of reasoning:

The majority of students [are] mixed and black. So, when you were talking about the data, I thought: - ah, for them this doesn't pose a problem because in the world where they live, everyone ends up the same. They don't have this experience of leaving and to have this experience, they would need to find themselves in another place, another context. Suddenly leave where they live and visit somewhere like the South Zone, for example. Then they would feel different. They would see the difference as a factor of inequality. But this they are still unable to perceive. I see the question of their lack of knowledge or even their alienation in relation to reality. I think it's a very big problem, also because it's linked to religion. Some [students] live completely oblivious to reality or limit themselves to accepting certain kinds of knowledge only due to a religious [Evangelical] doctrine. Of course, other factors exist that are less critical but that we cannot ignore, such as social problems, for example: how to live in an extremely violent environment that is not conducive to education.

Differences and inequalities, though closely connected, are evaluated in distinct ways by the teachers when it comes to questions of democracy, citizenship and otherness. The vision of a racially harmonious Brazil, denounced in the revisionist approach books (RABs) also seems to be a thing of the past in the views of the teachers. On diverse occasions, Brazil's racial experience was compared to the situation found in the USA, recognizing that there, just like here, racism is a pronounced feature of 
social interaction. A sociology teacher from a secondary school in Baixada Fluminense summarized his approach to the racial issue in the classroom:

I even talked a bit about Brazil in relation to this [racial divisions] and the question of miscegenation. It is clear from the figures - which actually contradict some thinkers - the figures show that we too are prejudiced, racism also exists in Brazilian society. This is something we have to combat, the figures show this. The figures that I'm talking about are social figures [...], whether on the issue of violence, on the quality of income, on the quality of jobs, show that this is our society. [...] When I get to Brazil today, I show that our reality is little different in social terms from American society.

While the revisionist approach books are emphatic about the need to respect differences, the teachers interviewed recognized that religious clashes have been the most recurrent issue in their classrooms, especially over recent years. Cases of personal abuse directed at followers of Afrodescendent religions by students linked to neo-Pentecostal (Evangelical) religions - which the RABs define as manifestations of intolerance - are on the increase in the perception of the teachers. A philosophy teacher from the Usina district (North Zone) made the following observation:

The theme of religion, when it surfaces - there's the issue of the pastor who is now head of the Human Rights commission, there are students who are deeply shocked because the discourse that he posts on Twitter, they think it must be a joke. For me it's still a striking question, but I already knew about it through my students, there are some students who reproduce exactly the same thing there [in class]. Black students, for example, who believe that they belong to a clan that has been cursed, I haven't heard that one or two times, I've heard it various times.

As some teachers told me, the 'passionate' way in which 'points of view' - either defending or denying the right to be different - end up being argued by students lead the teachers to avoid such clashes. Their common perception is that encouraging students to debate intolerance can often provoke clashes that culminate in more aggressive discussions. The teachers therefore need to be flexible enough to find more subtle forms of introducing the question. The history teacher from São João do Meriti sums up his strategy as follows: 
[The topic generates] many discussions, most of which have a religious base. What I find most difficult [is] making students aware, because we always work to raise awareness, a respect for differences, avoiding the reproduction of some situations that lead to physical or verbal abuse. In sum, various situations that we end up relating to prejudice. What most generates problems in terms of acceptance is respect for the other's religion. This generates a lot of discussion in the classroom, a lot: why do you need to respect it? Umbanda and Candomblé? The very names Umbanda and Candomblé are practically prohibited, [they say:] 'no... that's Macumba [associated with witchcraft]!" So it's impossible. I mean, it's just impossible. It's a situation of huge conflict. How do we work with history [...] in Year 6, speak about the history of Judaism, speak about polytheist civilizations, for me it's a real problem... There

\section{was one year when I said, I'm not going to talk about creationism and evolutionism, because I can't stand any more fights, I can't stand it any longer. (My emphasis)}

Although the school textbooks analysed here point to new forms of defining Brazilian society, in terms of its origin myth and the relation between its 'formative elements,' conferring new images (and directions?) to Brazilianness, concluding that this trend is hegemonic would be rash based on the uses made of these materials. While there is a search to 'standardize' the materials through the production of regulations and reference works (LDB, the Textbook Guide, PCN, Law 10.639, and so on) connected to specific discourses - such as the recognition of discrimination as an important factor in producing inequalities, and the recognition of differences as an important factor in defence of democracy - we can also perceive the possibility of an infinite number of approaches involving the partial use, adaptation, mixing or even avoidance of teaching materials approved by the State.

The participation in the International Seminar on Application of the Law for Teaching the History of Africa, held in October 2013, at the Institute of Philosophy and Social Sciences of the Federal University of Rio de Janeiro (IFCS/UFRJ) was especially important in terms of perceiving how teachers have come together to demand innovations in their training that can make them better prepared vis-à-vis the new discourses found in the textbooks.

Complementary materials, such as those produced by The Colour of Culture project, the result of a partnership between the Ministry of Education (MEC) and the Office for Policies Promoting Racial Equality, were 
cited as 'necessary but insufficient' resources for training Human Science professionals (in particular History graduates) in "the new ways of thinking about Brazil," as one of the interviewed teachers put it.

The research findings produced so far indicate the existence of contradictory stances concerning the production of a new sense of nation-ness through school textbooks. The Eurocentricism of traditional approaches, where the Portuguese cultural influence is seen to overshadow the contributions made by black and indigenous peoples, is criticised. Taking each culture in its own terms is seen as the secret for recognizing differences in defence of equality.

Inequalities are presented as the outcome of contradictions in the economic sphere, but also as an epiphenomenon of discrimination (including racial). Brazil is culturally and genetically one in the TABs, but many in the RABs: diverse ethnic groups, diverse regions, diverse social classes. The unified Brazil of the TABs is defined over and above its conflicts, while the fragmented Brazil of the RABs needs to learn to recognize and deal with its conflicts.

In the classroom, teachers work with both logics. They recognize that the conflicts of the past and the inequalities of the present are closely related. But, contradictorily, they see themselves as powerless to deal with today's differences - not only those apprehended in racial/ethnic terms, but also and especially those of religion and class. They are taken aback by the fragmentation of a Brazil once presented as unified in the TABs, while recognizing the feebleness of celebrating an integration today denounced as fake. They seem unsure which path to follow: that of an 'amalgamated Brazil' or a 'Brazil split asunder.'

Received 10 November2014, Approved 10 February 2015

Translated by David Rogers and Revised by Peter Fry

\section{Bibliography}

ABREU, Capistrano de. 1907. Capítulos de história colonial. FBN/Departamento Nacional do Livro (Domínio Público). Source: http:||objdigital.bn.br| Acervo_Digital/livros_eletronicos/capitulos_de_historia_colonia.pdf [Consulted: 15 November 2014].

ALTHUSSER, Louis. 1985. Sur la reproduction. Introduction de Jacques Bidet. Vendôme: Presses Universitaires de France. 
ANDERSON, Benedict 2005. Comunidades imaginadas: reflexões sobre a origem e a expansão do nacionalismo. Lisboa: Edições 70.

AUGUSTO DOS SANTOS, S. 2005. "Introdução”. In: Augusto dos Santos (ed.), Ações afirmativas e combate ao racismo nas Américas. Brasília: Ministério da Educação, Secretaria de Estado de Educação Continuada, Alfabetização e Diversidade.

AZEREDO, Paulo Roberto. 1986. Antropólogos e pioneiros: a história da Sociedade Brasileira de Antropologia e Etnologia. São Paulo: FFLCH/USP.

BANDECCHI, Brasil. 1973. História da civilização brasileira (Ensino Médio). São Paulo: LISA.

BARBOSA, Joaquim. 200o. "O uso da lei no combate ao racismo: direitos difusos e as ações civis públicas”. In: Antonio Sérgio Guimarães \& Lynn Huntley (eds.), Tirando a máscara: ensaios sobre o racismo no Brasil.São Paulo: Paz e Terra.

BRASIL. MINISTERIO DA EDUCAÇÃO. Parâmetros Curriculares Nacionais. Disponível em http:/|portal.mec.gov.br/par/195-secretarias-112877938/sebeducacao-basica-2007048997/12657-parametros-curriculares-nacionais50-a-80-series.

CARNEIRO, Maria Lucia Tucci. 1996. Racismo na História do Brasil: Mito e Realidade. Livro paradidático.

CARVALHO, José Murilo de. 2001. “Cidadania, estadania e apatia”. Jornal do Brasil, 24/06/01.

CASTELLAR, Sônia; ZAMBONI, Ernesta. 2004, História. Coleção Curimim. 2 série. São Paulo: Atual.

CHOPPIN, Alain. 2004. "História dos livros e das edições didáticas: sobre o estudo da arte”. Revista da Faculdade de Educação da USP. Educação \& Pesquisa, volume 30, n.3, p 549-566.

CHOR MAIO, Marco. 1999. "O Projeto Unesco e a agenda das ciências sociais no Brasil dos anos 40 e 50. RBCS, 41(14), p. 141 - 158.

; MONTEIRO, S. 2005. “Tempos de racialização: o caso da 'saúde da população negra no Brasil”. Hist. Ciências. Saude-Manguinhos, 12(2): p. $422-446$.

COTRIM, G. 1994. A história e consciência do Brasil. História e Consciência do Brasil. São Paulo: Saraiva.

COSTA, Sergio. 2003. "Os paradoxos do pensamento brasileiro”. Teoria e Pesquisa, 42/43, p. $111-146$. 
COSTA JR., C. 2007. História. Projeto Buriti. 2 ano. Manual do Professor. São Paulo: Moderna, .

DREGUER, R.; MARCONI, C. 2009. História. Col. Conviver. 2 ano. Livro do Aluno. São Paulo: Moderna.

ABILA FILHO, José. 1977. Enciclopédia ilustrada para educação básica (Ensino Fundamental). Curitiba: Editora Educacional Brasileira.

FOUCAULT, Michel. 1981. Microfísica do poder. Rio de Janeiro: Graal. 1988. A história da sexualidade I: a vontade de saber. Rio de Janeiro: Editora Graal.

FREITAG, Barbara; MOTTA, Valéria.; COSTA, Wanderly. 1997. O livro didático em questão. São Paulo: Cortez.

FRY, Peter. 2007. "Social scientists and the dispute over meaning of race in Brazil”. Colloque Les Nouveaux Essentialism, Paris, URCIM. Mimeo GASTAL, Maria de Lourdes. 1961. Estudos sociais e naturais - 3 ano primário. Porto Alegre: Editora Globo.

GUIMARÃES, Antônio Sérgio A. 2002 Classes, raças e democracia. São Paulo: Editora 34.

HANCHARD, Michael. 2001. Orfeu e o poder: Movimento Negro no Rio e São Paulo. Rio de Janeiro:EdUERJ.

HANSEN, Patricia (200o). Feições e fisionomia. A História do Brasil de João Ribeiro. Rio de Janeiro: Access.

HASENBALG, Carlos. 1979. Discriminação edesigualdades raciais no Brasil. Rio de Janeiro: Graal.

HOCHMAN, Gilberto. 1998. A era do saneamento: as bases da política de saúde pública no Brasil. São Paulo: Hucitec/Anpocs.HOFBAUER, Andreas. 2009. "Entre olhares antropológicos e perspectivas dos estudos culturais e pós-coloniais: consensos e dissensos no trato das diferenças”. Revista Antropolítica 27. p. 99-130.

LINS, Ana Luiza . 2008. História. Coleção Tantas Histórias. 5 . ano. São Paulo: FTD.

LIPPI OLIVEIRA, Lúcia. 2000. "O imaginário histórico e poder cultural: As comemorações do descobrimento”. Estudos Históricos, 14(26): p. 183-202.

LUCA, Tânia.; MIRANDA, Sônia. 2004. “O livro didático de história hoje: um panorama a partir do PNLD”. Rev. Bras. Hist., 24(48), p. 123 - 148.

LUCCI, Elian; BRANCO, Anselmo 2008. História. Viver e aprender. São Paulo: Saraiva. 
MACEDO, Roberto. 1963. Eles fizeram a história do Brasil. Rio de Janeiro: Distribuidora Record.

MAGALHÃES, Basílio. 1952. História do Brasil. Curso clássico e científico. 2a série. Rio de Janeiro: Livraria Francisco Alves.

MAGALHÃES, Basílio. 1958. História do Brasil. Curso clássico e científico. 2a série. Rio de Janeiro: Livraria Francisco Alves.

MAGGIE, Yvonne. 2005. "Mario de Andrade ainda vive? O ideário modernista em questão”. Revista Brasileira de Ciências Sociais, 58: p. 5-25.

MANTOVANI, K. 2009. O Programa Nacional do Livro Didático: impactos na qualidade do ensino público. MA dissertation. FFL/USP.

MARISTAS (Collection) . 1957. História do Brasil. 4a série ginasial. São Paulo: Editora do Brasil.

MONTEIRO, F. D. 2010. Do antirracismo criminal às ações afirmativas: um estudo sobre o debate político racial no Rio de Janeiro (2000-2007). PhD thesis, PPGSA/UFRJ.

MOREIRA, João Carlos.; SENE, Eustáquio de. 2004. Geografia geral e do Brasil. Espaço geográfico e do Brasil (Ens. Médio). São Paulo: Ed. Scipione. MOTA, Carlos .Guilherme. 1990. “Cultura brasileira ou cultura republicana?”. Revista de Estudos Avançados, 4(8), p. 19 - 38.

MOTA, Myriam Becho; BRAICK, Patrícia Ramos. 200o. História: da caverna ao terceiro milênio. Livro do Professor.Rio de Janeiro: Editora Moderna.

MUNDURUKU, Daniel (200o). Coisas de Índio. São Paulo: Callis.

Nogueira, Oracy 1955. 'Preconceito racial de marca e preconceito racial de origem', em Anais do XXXI Congresso Internacional de Americanistas e na separata relativa ao Symposium Etno-sociológico sobre Comunidades Humanas no Brasil. São Paulo.

REIS, J. C. 2007. As inidentidades do Brasil 1:de Varnhagem a FHC. Rio de Janeiro: FGV.

RIBEIRO, João. 1957 [1901]. História do Brasil. Florianópolis: São José.

ROSEMBERG, Fulvia. et al. 2003. "Racismo em livros didáticos brasileiros e seu combate: uma revisão da literatura”. Educação e Pesquisa, 29(1): 125146.

SALVADORI, Maria.; FERNANDES, Jane. 2006. História. Coleção Trilhos e Trilhas. $4^{a}$. série. Manual do Professor. São Paulo: Editora Saraiva.

SANT'ANNA, Wânia. 2001. "Novos marcos para as relações étnico-raciais no Brasil: uma responsabilidade coletiva”. In: Gilberto Vergne Saboia 
(org.), Anais de Seminários Regionais Preparatórios para Conferência Mundial contra Racismo, Discriminação, Xenofobia e Intolerância correlata. Brasília: Ministério da Justiça/ Secretaria de Estado dos Direitos Humanos.

SEYFERTH, Giralda. 1989. "As ciências sociais no Brasil e a questão racial "In: Cativeiro e Liberdade, Publicação do Seminário de Filosofia e Ciências Sociais da Universidade do Estado do Rio de Janeiro.

SORJ, Bernardo. 2000. A nova sociedade brasileira. Rio de Janeiro: Jorge Zahar. WITZEL, D.G. 2002. Identidade e llivro didático. Movimentos identitários do professor de língua portuguesa. Maringá, MA disssertation, UEM.

Fabiano Dias Monteiro

fdmrio@gmail.com 